\title{
Determination of Metoclopramide Hydrochloride in Pharmaceutical Formulations Using Three Different Spectrophotometric Methods
}

\section{Naggar $\mathbf{A H}^{\star}$, Elnasr TAS, Sayed Ali AS, Kotb A and EI Sayed AAY}

Chemistry Department, Faculty of Science, Al-Azhar University, 71524, Assiut, Egypt

*Corresponding author: Naggar AH, Chemistry Department, Faculty of Science, Al-Azhar University, Assiut Branch, 71524, Assiut, Egypt, Tel: 00201011671088; Email: ahmed2003hosny@yahoo.com

Received date: October 20, 2016; Accepted date: February 25, 2017; Published date: February 28, 2017

Copyright: () 2017 Naggar AH, et al. This is an open-access article distributed under the terms of the Creative Commons Attribution License, which permits unrestricted use, distribution, and reproduction in any medium, provided the original author and source are credited.

\section{Abstract}

Three simple, selective, accurate and precise spectrophotometric methods were developed for the determination of Metoclopramide Hydrochloride (MCP) in dosage forms. The first method (Method $A$ ) is based on coupling reaction of diazotized MCP with 2,5-diphenyl-2,4-dihydro-pyrazol-3-one (DPP) in alkaline medium to form azo dye. The second method (Method $B$ ) is based on Schiff's base formation reaction between MCP and 4-hydroxybenzaldehyde (HBD). The last method (Method C) is based on the formation of colored ion-pair complex from the reaction of MCP with Eosin $Y(E S N)$. Beer's law was obeyed in the concentration range of 1.35-40.37, 1.01-5.05 and 1.01-10.09 $\mu \mathrm{g} / \mathrm{mL} \mathrm{MCP} \mathrm{at} \mathrm{426,} 386$ and $543 \mathrm{~nm}$ with molar absorptivity of $1.51 \times 10^{4} \mathrm{~L} \mathrm{~mol}^{-1} \mathrm{~cm}^{-1}, 2.10 \times 10^{4} \mathrm{~L} \mathrm{~mol}^{-1} \mathrm{~cm}^{-1}$ and $3.34 \times 10^{4} \mathrm{~L} \mathrm{~mol}^{-1} \mathrm{~cm}^{-1}$ for Method A, Method B and Method C, respectively. The proposed methods were successfully applied to the determination of MCP in pharmaceutical preparations without any interference from common excipients.
\end{abstract}

Keywords: Metoclopramide; Coupling reaction; Schiff's base; Ionpair complex; Spectrophotometry; Pharmaceutical

\section{Introduction}

Metoclopramide hydrochloride (MCP), monohydrate of 4-amino-5chloro-N-[(2-diethyl amino)ethyl]-2-methoxy benzamide mono hydrochloride (Figure 1), is a substituted benzamide and commonly used as an anti-emetic in the management of some forms of nausea and vomiting and for stimulating the motility of the upper gastrointestinal tract [1]. MCP decreases stomach acid reflux by strengthening the lower esophagus sphincter. MCP also hastens the stomach emptying of solid and liquid meals into the intestines. Rapid emptying of meals also helps decrease the reflux of stomach acid and other contents into the esophagus [2]. It is also used in the prevention of cancer chemotherapy induced emesis [3].

Different analytical methods were used for the determination of MCP. These methods include voltammetric [4-10], potentiometric [11-13], chromatographic methods [14-19]. There is no doubt that some of these methods are sensitive and selective, but they require expensive instruments, accessories, and solvents, not to mention their demand for cleaning procedures.

Although the rise of such modern sensitive analytical methods, spectral analysis remains the best choice in many laboratories, especially analytical ones aimed to drugs determination. This can be attributed to its simplicity, cost effectiveness, sensitivity and selectivity, and fair accuracy and precision. Through literature survey, it was revealed different analytical procedures were used for the spectrophotometric determination of MCP. These spectrophotometric procedures include derivative spectrophotometric [19,20], UV spectrophotometric [21-23] and sequential injection spectrophotometric [24,25]. Several spectrophotometric methods based on diazo-coupling reaction [26-36], Schiff's base reaction
[36-39], ion-pair complex reaction [40,41], charge-transfer reaction $[42,43]$ and redox reaction [44,45] were described. Also, spectrofluorimetric methods for MCP determination were suggested [46-48].

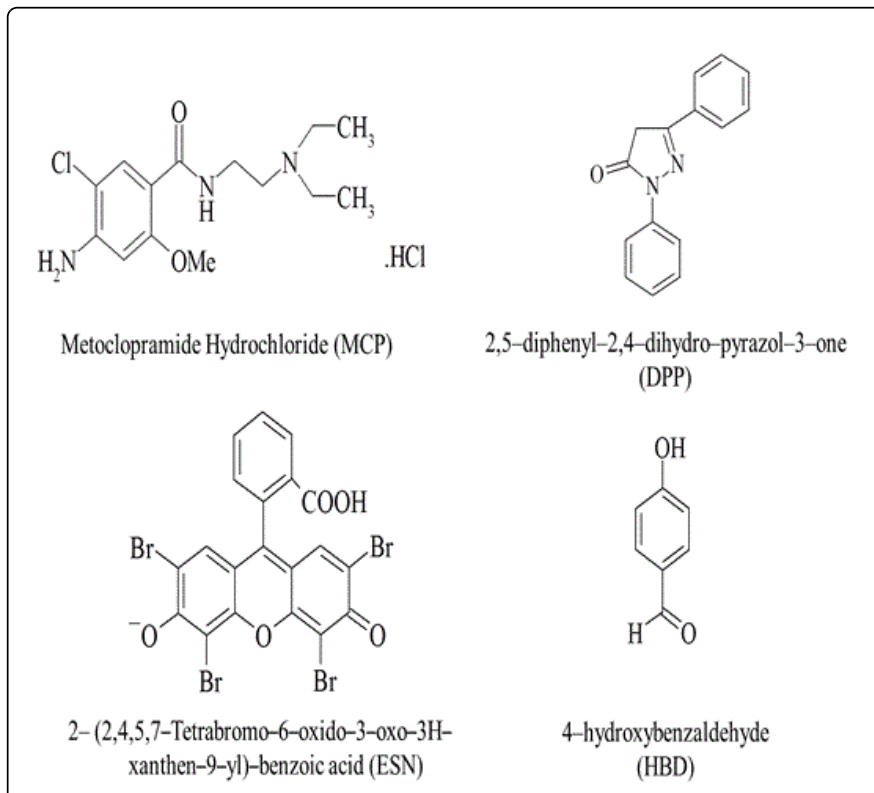

Figure 1: Chemical structure of MCP, DPP, HBD and ESN.

To the best of our knowledge, little attentions had been made to spectrophotometric determination of MCP either using chargetransfer reaction or ion-pair complex and the literature are still poor in such analytical procedure. In this article, we present three simple, sensitive and selective spectrophotometric procedures for MCP 
Citation: Naggar AH, Elnasr TAS, Sayed Ali AS, Kotb A, El Sayed AAY (2017) Determination of Metoclopramide Hydrochloride in Pharmaceutical Formulations Using Three Different Spectrophotometric Methods. Pharm Anal Acta 8: 538. doi: $10.4172 / 2153-2435.1000538$

Page 2 of 9

determination. The first method (Method A) is based on coupling reaction of diazotized MCP with 2,5-diphenyl-2,4-dihydro-pyrazol-3one (DPP) in alkaline medium. The second method (Method B) is based on reaction of MCP with 4-hydroxybenzaldehyde (HBD) to produce Schiff's base colored complex. The last method (Method C) is based on the formation of colored ion-pair complex from the reaction of MCP with Eosin Y (ESN). In the studied wavelength range, individual MCP solution doesn't have absorption maxima. So, the recorded absorption maxima are related to the formed MCP colored compound. The presented color reactions provide an inexpensive way for the spectrophotometric determination of MCP at a considerable low concentration. The developed procedures were successfully used in the determination of MCP in its pharmaceuticals preparation.

\section{Experimental}

\section{Apparatus}

All absorption measurements were carried out using a Perkin-Elmer model Lambda 3B double-beam UV-visible programmable spectrophotometer, equipped with $1 \mathrm{~cm}$ quartz cell and controlled by a PC running the spectrophotometric software PECSS. PECSS PerkinElmer software program was used for data analysis with slit-width, 1 $\mathrm{nm}$; scan speed, $120 \mathrm{~nm} / \mathrm{min}$ and wavelength interval, $1 \mathrm{~nm}$. All the pH measurements were made using VWR Scientific Products Model 2000, USA.

\section{Materials and reagents}

All chemicals used were analytical reagent grade and used without further purification. Metoclopramide hydrochloride (MCP) was purchased from Merck. The pharmaceutical preparations used in the present investigation were Primperan tablets and Plasil ampoules (Sanofi Aventis Egypt Company), labelled to contain $10 \mathrm{mg} /$ tablet and $10 \mathrm{mg}$ /ampoule, respectively. Reagents like 4-hydroxybezaldehyde (HBD) and Eosin Y (ESN) were purchased from Merck.

\section{Preparation of MCP stock standard and reagents solutions}

Standard solution of MCP: A stock standard solution of MCP $(1 \times$ $10^{-2} \mathrm{M}$ ) was prepared by dissolution $0.3363 \mathrm{~g}$ of the authentic drug in $100 \mathrm{~mL}$ volumetric flask containing distilled water, the volume was completed with the same solvent and kept in a brown volumetric flask. MCP working solutions were prepared daily by sequential dilution of the stock standard solution using distilled water.

Pharmaceuticals preparations: Ten tablets of Primperan tablets were weighed into a small dish, powdered and mixed well. A portion of the ground tablets equivalent to $0.05 \mathrm{~g}$ of MCP was accurately weighed and dissolved in $50 \mathrm{~mL}$ distilled water, shaken well and filtrated using a filter paper. An aliquot of filtrate was transferred into $50 \mathrm{~mL}$ volumetric flask and it was completed to the mark with distilled water. Working solutions were prepared by serial dilution of the resulting solution using the same solvent.

The content of six Plasil ampoules were quantitatively transferred into $50 \mathrm{~mL}$ volumetric flask and completed to the mark with distilled water. Working solutions were prepared by serial dilution of the resulting solution using the same solvent.

\section{Reagents and buffers solutions}

For the preparation of 2,5-diphenyl-2,4-dihydro-pyrazol-3-one (DPP), $19.244 \mathrm{~g}$ of ethyl benzoyl acetate was placed in a round flask in oil bath at about $120^{\circ} \mathrm{C}$ with slow drop wise addition of $10.791 \mathrm{~g}$ distilled phenyl hydrazine solution. The reaction mixture was maintained under the condenser for $1 \mathrm{hr}$. A crystalline deposited precipitate was separated and washed with diethyl ether several times [49]. A Stock solution of DPP $\left(1.7 \times 10^{-2} \mathrm{M}\right)$ was prepared by dissolving $2.0 \mathrm{~g}$ of pure material in $0.3 \mathrm{M} \mathrm{NaOH}$, then complete to 500 $\mathrm{mL}$ in a volumetric flask with the same solvent.

A stock solution of HBD $\left(8.2 \times 10^{-2} \mathrm{M}\right)$ was prepared by dissolving $5.0 \mathrm{~g}$ of HBD in glacial acetic acid, while ESN $\left(3.6 \times 10^{-4} \mathrm{M}\right)$ was prepared by dissolving $0.125 \mathrm{~g}$ of ESN in distilled water. Either in case of $\mathrm{HBD}$ or ESN, complete to $500 \mathrm{~mL}$ in a volumetric flask with the same solvent.

\section{Recommended procedures}

Method A: Coupling reaction of diazotized MCP with DPP: In 25 $\mathrm{mL}$ volumetric flask (in ice bath), place aliquot of sample solution containing 1.35-40.4 $\mu \mathrm{g} / \mathrm{mL}$ of MCP, $3.5 \mathrm{~mL} \mathrm{HCl}(0.2 \mathrm{M}), 2.5 \mathrm{~mL}$ $\mathrm{NaNO}_{2}(0.04 \mathrm{M}), 5.0 \mathrm{~mL}$ of $0.014 \mathrm{M}$ DPP, $7.0 \mathrm{~mL} \mathrm{KCl-NaOH}$ buffer solution $(\mathrm{pH} \approx 11.2)$ [50], and complete to the mark with distilled $\mathrm{H}_{2} \mathrm{O}$. Mix the components well. After $10 \mathrm{~min}$., the absorbance was measured at $426 \mathrm{~nm}$ against the reagent blank.

Method B: Schiff's base colored complex formed by reaction of MCP with HBD: In $10 \mathrm{~mL}$ volumetric flask, place an aliquot of sample solution containing 1.01-5.04 $\mu \mathrm{g} / \mathrm{mL}$ of MCP, $3.5 \mathrm{~mL}$ of $8.2 \times 10^{-2} \mathrm{M}$ HBD, $3.10 \mathrm{~mL}$ of Conc. $\mathrm{H}_{2} \mathrm{SO}_{4}$ (98\%), complete to the mark with glacial acetic acid and shake well. The absorbance was measured at 386 $\mathrm{nm}$ against the reagent blank.

Method C: Ion-pair colored complex formed by reaction of MCP with ESN: In $10 \mathrm{~mL}$ volumetric flask, place an aliquot of sample solution containing 1.01-10.09 $\mu \mathrm{g} / \mathrm{mL}$ of MCP, $2.5 \mathrm{~mL}$ distilled $\mathrm{H}_{2} \mathrm{O}$ and $4.0 \mathrm{~mL} 3.6 \times 10^{-4} \mathrm{M}$ ESN and $3.0 \mathrm{~mL}$ Mcilvaine's buffer $(\mathrm{pH} \approx 3.2)$ [51]. Complete to the mark with distilled water and shake well. The absorbance was measured at $543 \mathrm{~nm}$ against the reagent blank.

\section{Procedure for the determination of MCP in tablets and ampoules}

MCP in dosage forms (tablets and ampoules) was determined according to the standard addition method. In previously described procedures, a definite volume of the sample solution was added in specified volumetric flask followed by successive additions of standard MCP solution. The absorbance was measured at 426, 386 and $543 \mathrm{~nm}$ for DPP, HBD and ESN, respectively.

\section{Results and Discussion}

\section{Spectral characteristics}

Method A: Coupling reaction of diazotized MCP with DPP: Whereas DPP has an active methylene group; it has a great ability to form an azo colored compound with diazotized MCP in an aqueous alkaline medium. The most important feature of this product, that it's completely soluble in reaction medium, there is no need to additional step to solubilize this product for spectrophotometric analysis. The reaction could be explained in Figure 2. The absorption spectra of 
Citation: Naggar AH, Elnasr TAS, Sayed Ali AS, Kotb A, El Sayed AAY (2017) Determination of Metoclopramide Hydrochloride in Pharmaceutical Formulations Using Three Different Spectrophotometric Methods. Pharm Anal Acta 8: 538. doi: $10.4172 / 2153-2435.1000538$

Page 3 of 9

blank solution (contains DPP) and coupling reaction product (diazotized MCP-DPP) are shown in Figure 3 (curves a and b, respectively). The absorption maximum of the produced azocompound was at $426 \mathrm{~nm}$; hence, all measurements were made at this wavelength against reagent blank.

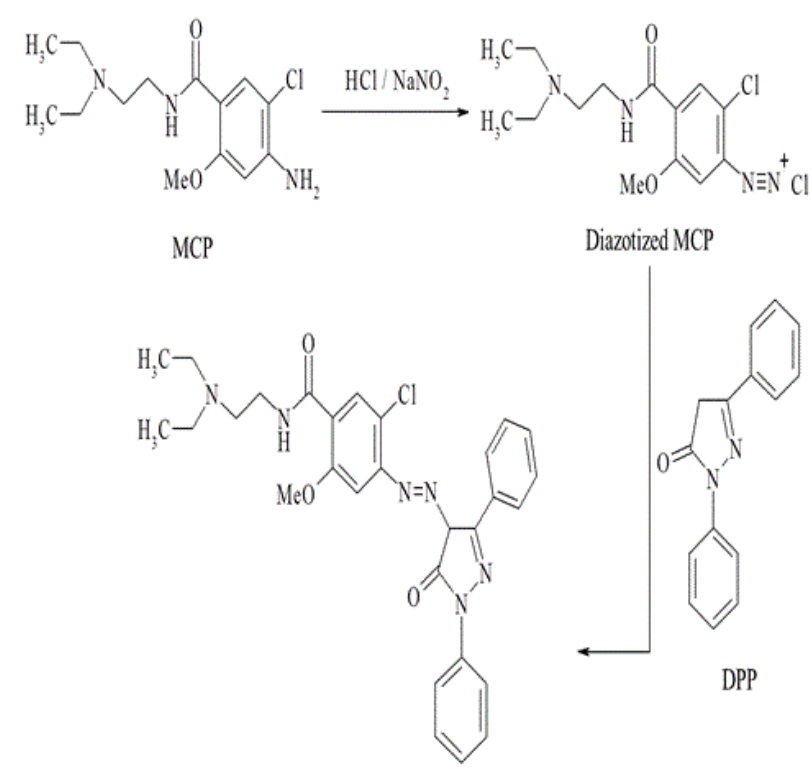

Figure 2: Suggested scheme for coupling reaction between diazotized MCP and DPP.

Method B: Schiffs base colored complex formed by reaction of MCP with HBD: For Schiff's base formation, HBD was selected as aromatic aldehyde to react with MCP. The condensation reaction requires the presence of an acid for the protonation of the carbonyl oxygen and thereby leaving the carbonyl carbon fully positive charge. In current procedure, Conc. $\mathrm{H}_{2} \mathrm{SO}_{4}$ is used for this purpose. Amino group in MCP have a great ability to donate a lone pair of electrons to the carbon present in the carbonyl group of HBD. Internal rearrangement thereafter results in the formation of imine (Schiff's base) and then giving water and proton as by-products [52]. The reaction mechanism can be illustrated Figure 4. The absorption spectra of blank solution (contains HBD) and MCP-HBD reaction product are shown in Figure 5 (curve $a$ and $b$, respectively). The maximum absorbance of the produced Schiff's base was observed at $386 \mathrm{~nm}$. Hence, all measurements were made at this wavelength against reagent blank.

Method C: Ion-pair colored complex formed by reaction of MCP with ESN: As can be seen in Figure 6, ESN structure shows the presence of both a carboxylic and a phenolic group; the latter is highly affected by the presence of the 4-electron withdrawing bromine atoms. As a result, the $\mathrm{pKa}(\mathrm{OH})$ becomes less than $\mathrm{pKa}(\mathrm{COOH})(2.02$ and 3.8 , respectively) [53]. Therefore, at $\mathrm{pH} 3.2$ the $\mathrm{OH}$ group becomes most likely fully ionized and thus electrostatically interacts with the primary amino group of MCP forming the orange-red ion-pair complex. Figure 6 shows the suggested reaction pathway. The absorption spectra of the blank solution (contains ESN) and MCP-ESN ion-pair complex are shown in Figure 7 (curve a and b, respectively). MCP reacts instantly with ESN in acidic medium and a bathochromic shift of the dye about $30 \mathrm{~nm}$ was produced indicating the forming the orange-red ion-pair complex. All measurements were carried out at $543 \mathrm{~nm}$.

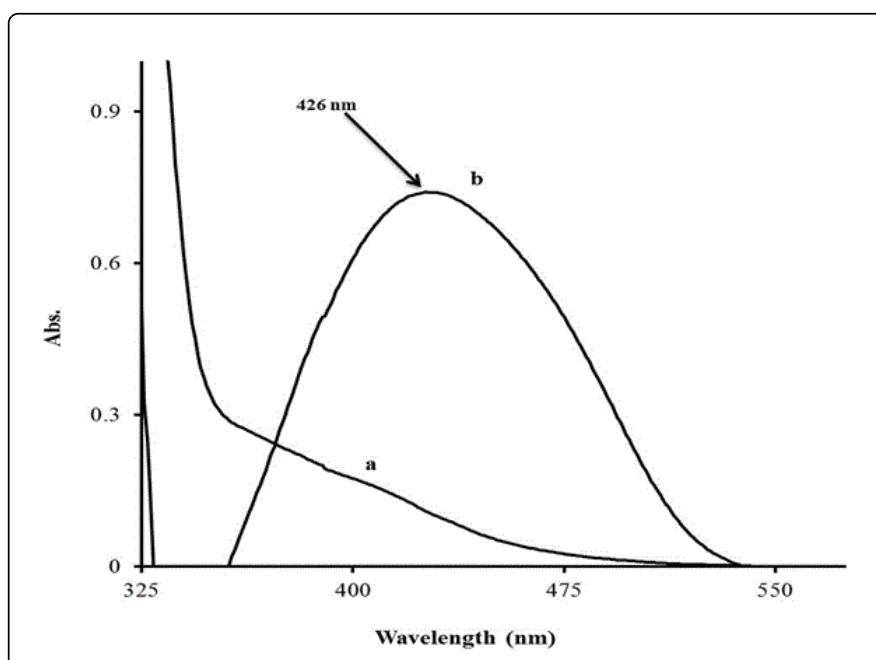

Figure 3: Spectral curves of (a) blank solution contain DPP and (b) colored azo compound of diazotized MCP-DPP $\left(4.8 \times 10^{-5} \mathrm{M} \mathrm{MCP}\right.$ and $2.8 \times 10^{-3} \mathrm{M}$ DPP, $\lambda_{\max }=426 \mathrm{~nm}$ ).

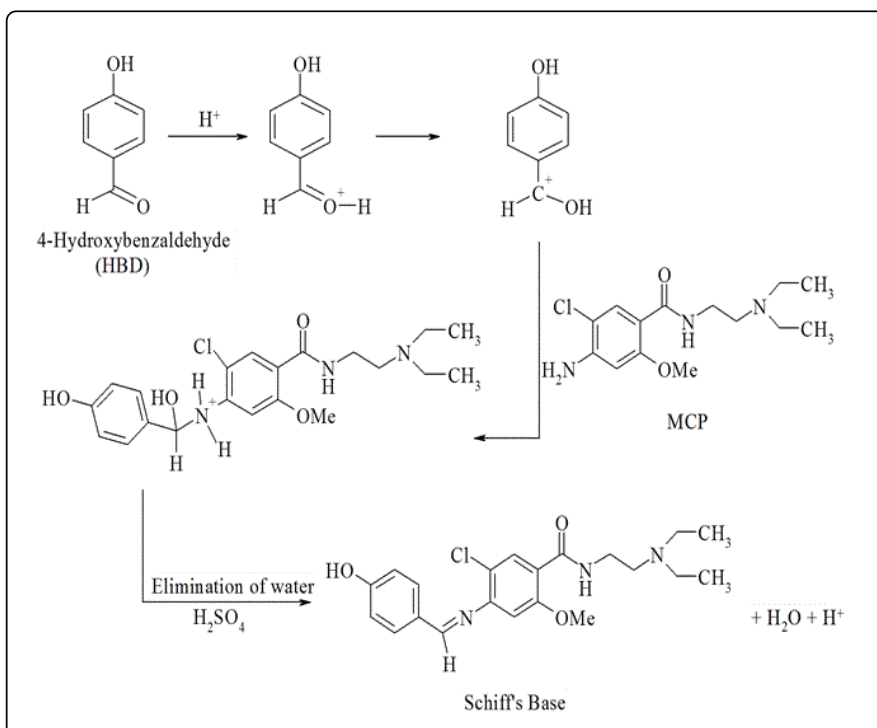

Figure 4: Suggested scheme for Schiff's base formation reaction between MCP and HBD.

\section{Optimization of experimental variables}

Different experimental parameters which affect the color intensity and stability were carefully studied and optimized. Such parameters were changed individually while keeping the others constant. The optimized experimental variables for all proposed methods were recorded in Table 1. 
Citation: Naggar AH, Elnasr TAS, Sayed Ali AS, Kotb A, El Sayed AAY (2017) Determination of Metoclopramide Hydrochloride in Pharmaceutical Formulations Using Three Different Spectrophotometric Methods. Pharm Anal Acta 8: 538. doi: $10.4172 / 2153-2435.1000538$

Page 4 of 9

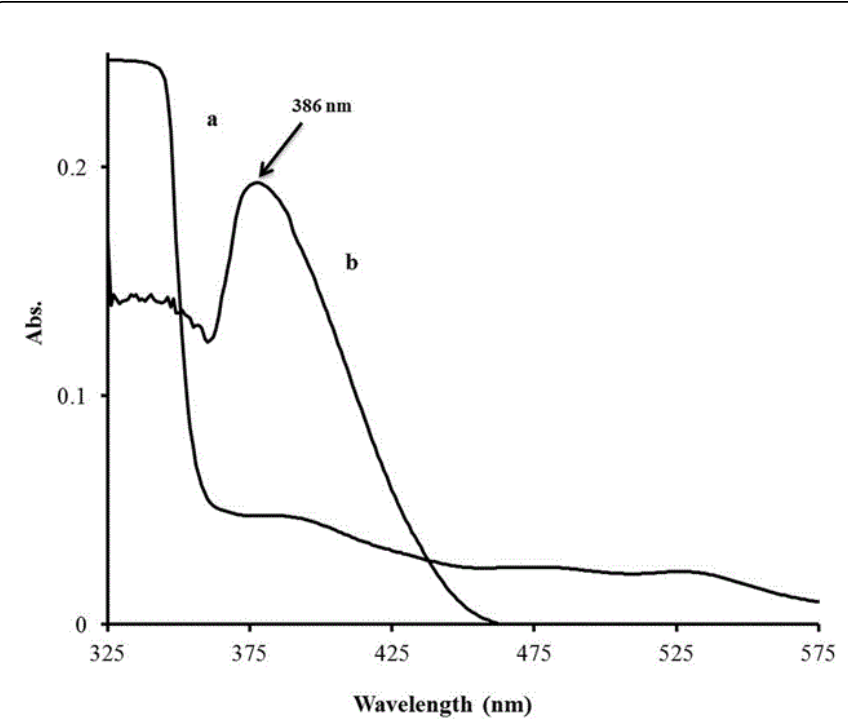

Figure 5: Spectral curves of: (a) blank solution contains HBD, (b) MCP-HBD reaction product (using $8.9 \times 10^{-6} \mathrm{M} \mathrm{MCP}$ and $2.87 \times$ $10^{-2} \mathrm{M}$ of HBD in presence $3.5 \mathrm{~mL}$ of Conc. $\mathrm{H}_{2} \mathrm{SO}_{4}, \lambda_{\max }=386 \mathrm{~nm}$ ).<smiles>O=C(O)c1ccccc1-c1c2cc(Br)c(=O)c(Br)c-2oc2c(Br)c([O-])c(Br)cc12</smiles>

ESN<smiles>CCN(CC)CCNC(=O)c1cc(Cl)c(N)cc1OC</smiles>

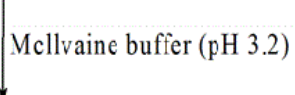

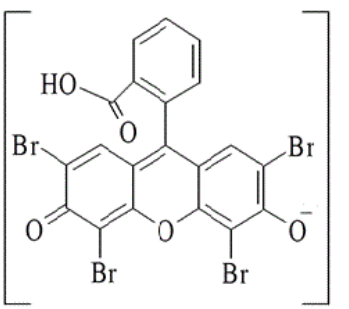<smiles>CCN(CC)CCNC(=O)c1cc(Cl)c(N)cc1OC</smiles>

Figure 6: Suggested scheme for the formation of colored ion-pair complex as a product of reaction between MCP and ESN.

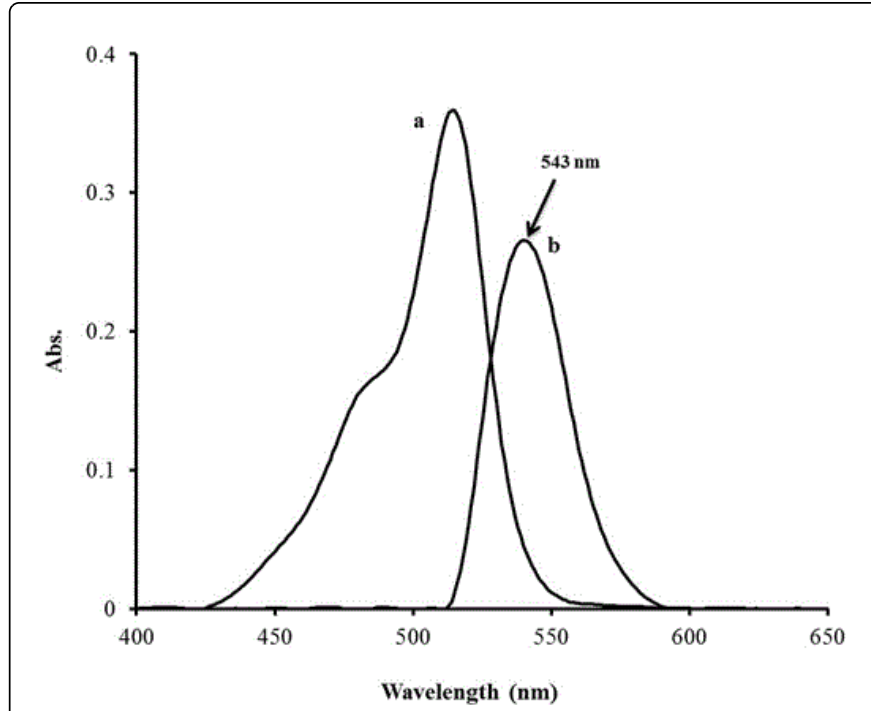

Figure 7: Spectral curves of MCP-ESN binary complex: (a) Blank solution contains ESN; (b) MCP-ESN (using $1.78 \times 10^{-5} \mathrm{M}$ MCP, 7.2 $\times 10^{-5} \mathrm{M}$ ESN and $3 \mathrm{~mL}$ Mcllvaine buffer $\mathrm{pH} \approx 3.2, \lambda_{\max }=543 \mathrm{~nm}$ ).

\begin{tabular}{|c|c|c|c|}
\hline Parameter & Method A & Method B & Method C \\
\hline Procedure & $\begin{array}{l}\mathrm{MCP}+\mathrm{HCl} \\
+\mathrm{NaNO}{ }_{2}+\mathrm{DPP}+\mathrm{NaOH}- \\
\mathrm{KCl} \text { soln. }\end{array}$ & $\begin{array}{l}\mathrm{MCP}+\mathrm{HBD}+\text { Conc. } \\
\mathrm{H}_{2} \mathrm{SO}_{4}\end{array}$ & $\begin{array}{l}\text { MCP+ESN } \\
\text { +Buffer } \\
\text { solution }\end{array}$ \\
\hline $\begin{array}{l}\text { Reagent } \\
\text { Conc. (M) }\end{array}$ & $2.8 \times 10^{-3}$ & $2.87 \times 10^{-2}$ & $1.44 \times 10^{-4}$ \\
\hline $\begin{array}{l}\text { Temperature } \\
\left({ }^{\circ} \mathrm{C}\right)\end{array}$ & Ice bath & Room temperature & $\begin{array}{l}\text { Room } \\
\text { temperature }\end{array}$ \\
\hline Time (min) & 10 & instantaneous & instantaneous \\
\hline $\begin{array}{l}\text { Buffer/ } \\
\text { Medium type }\end{array}$ & $\mathrm{NaOH}-\mathrm{KCl}$ & - & $\begin{array}{l}\text { Mcllvaine } \\
\text { buffer }\end{array}$ \\
\hline $\begin{array}{l}\text { Buffer/ } \\
\text { Medium } \\
\text { volume }(\mathrm{mL})\end{array}$ & 7 & - & 3 \\
\hline $\mathrm{pH}$ & 11.2 & - & 3.2 \\
\hline $\begin{array}{l}\mathrm{HCl} \text { Conc. } \\
\text { (M) }\end{array}$ & $2.8 \times 10^{-2}$ & - & - \\
\hline $\begin{array}{l}\mathrm{NaNO}_{2} \text { Conc. } \\
\text { (M) }\end{array}$ & $4.0 \times 10^{-3}$ & - & - \\
\hline $\begin{array}{l}\mathrm{H}_{2} \mathrm{SO}_{4} \text { Conc. } \\
(\%)\end{array}$ & - & 30.6 & - \\
\hline
\end{tabular}

Table 1: The selected optimum conditions of suggested procedures for MCP spectrophotometric determination.

Method A: Coupling reaction of diazotized MCP with DPP: Different factors affect azo dye formation includes $\mathrm{pH}$ and concentration of each of $\mathrm{HCl}, \mathrm{NaNO}_{2}, \mathrm{DPP}$ and $\mathrm{KCl}-\mathrm{NaOH}$ buffer were studied and optimized. Such factors were changed individually while others were kept constant. 
Citation: Naggar AH, Elnasr TAS, Sayed Ali AS, Kotb A, El Sayed AAY (2017) Determination of Metoclopramide Hydrochloride in Pharmaceutical Formulations Using Three Different Spectrophotometric Methods. Pharm Anal Acta 8: 538. doi: $10.4172 / 2153-2435.1000538$

Page 5 of 9

The effect of $\mathrm{pH}$ on the absorbance intensity of MCP at $426 \mathrm{~nm}$ was studied using Britton-Robinson buffer over the $\mathrm{pH}$ range of 9.2-11.8. In addition to Britton-Robinson, the absorbance was recorded in different types of buffers like $\mathrm{KCl}-\mathrm{NaOH}, \mathrm{Na}_{2} \mathrm{HPO}_{4}-\mathrm{NaOH}, \mathrm{NaHCO}_{3}-$ $\mathrm{NaOH}$ and Borax- $\mathrm{NaOH}$ to select the best choice to be used in further studies. The obtained results indicate that highest absorbance was recorded in $\mathrm{KCl}-\mathrm{NaOH}(\mathrm{pH} \approx 11.20)$.

The effect of other additives concentration on the determination of MCP was studied in terms of additive volume. This study was established for $\mathrm{HCl}$ (4-64 mM), $\mathrm{NaNO}_{2}$ (0.8-8 mM), DPP (0.28-5.6 $\mathrm{mM})$ and $\mathrm{KCl}-\mathrm{NaOH}(2-10 \mathrm{~mL})$, where absorbance was recorded at $426 \mathrm{~nm}$. The results showed that reproducible color intensity and stability of formed dye was obtained at $28 \mathrm{mM} \mathrm{HCl}, 4 \mathrm{mM} \mathrm{NaNO}_{2}, 2.8$ $\mathrm{mM}$ DPP and $7 \mathrm{~mL} \mathrm{KCl-NaOH}(\mathrm{pH} \approx 11.20$ ). The optimum reaction time was determined by monitoring the color development. It was found that the colored product is formed immediately and becomes stable after $10 \mathrm{~min}$ and remains constant for more than $180 \mathrm{~min}$

Method B: Schiffs base colored complex formed by reaction of MCP with HBD: Different experimental parameters affecting the formation of Schiff's base colored complex as a product of reaction between MCP and HBD were carefully studied and optimized. It was observed that the analytical signal increased with an increase $\mathrm{H}_{2} \mathrm{SO}_{4}$ and HBD concentration in range of $4.9-44.1 \%$ and $4.1 \times 10^{-3}-3.28 \times$ $10^{-2} \mathrm{M}$, respectively. The selected values which corresponding maximum absorbance was $30.6 \%$ and $2.87 \times 10^{-2} \mathrm{M}$ for $\mathrm{H}_{2} \mathrm{SO}_{4}$ and $\mathrm{HBD}$, respectively. In current procedure, $\mathrm{MCP}$ failed to give condensation product with $\mathrm{HBD}$ even in the presence of $\mathrm{H}_{2} \mathrm{SO}_{4}$. Yellow colored product was developed only in glacial acetic acid medium; so, glacial acetic acid was used as the solvating solvent. After optimizing all other experimental variables, further experiments were performed to ascertain the influence of order of addition of reactants on the color development. Maximum sensitivity was achieved when $\mathrm{HBD}$ was mixed with MCP followed by $\mathrm{H}_{2} \mathrm{SO}_{4}$ addition. Finally, the reaction was found to be instantaneous and the colored product approximately stable for $3 \mathrm{~h}$. So, the absorbance readings were recorded instantly.

Method C: Ion-pair colored complex formed by reaction of MCP with ESN: In order to optimize the investigated reaction, different parameters were extensively studied in order to yield the highest and most reproducible absorbance readings. The acidic $\mathrm{pH}$ is a fundamental factor affecting the ionization of ESN thus allowing its interaction with MCP. For this reason, at constant $\mathrm{pH}$ value, different buffers (acetate, citrate and Mcllvaine) were studied among which the Mcllvaine buffer gave the best results. Accordingly, this buffer was further tried in different ranges of volumes (1.0-5.0 mL) and $\mathrm{pH}$ values (2.2-4.2). $3.0 \mathrm{~mL}$ of Mcllvaine buffer $\mathrm{pH} 3.2$ gave the highest absorbance readings. Investigation of the effect of the ESN concentration revealed that $4.0 \mathrm{~mL}$ of $3.6 \times 10^{-4} \mathrm{M} \mathrm{ESN}\left(1.44 \times 10^{-4} \mathrm{M}\right.$ final concentration in total volume of $10 \mathrm{~mL}$ ) gave the maximum absorbance and was chosen to be the suitable concentration for the analytical procedure. Generally, the limited aqueous solubility of the produced drug-dye complexes was solved by either extracting the complex with an organic solvent [54] or adding a non-ionic surfactant as methyl cellulose [55]. Alternatively, El-Brashy et al. [56] reported a simpler solution for such a problem, which is based on keeping the sample concentration at maximum dilution before adding the dye solution and mixing the solution well before the addition of buffer solution. Accordingly, by adopting the above procedure, the stability and solubility of the produced MCP-ESN complex were achieved without the need of lengthy extraction steps or the use of non-ionic surfactants.

The intensity of the final color was maxima at room temperature. It was observed that with increasing temperature, a precipitate was produced which may be due to coagulation of the formed complex. Finally reaction was found to be instantaneous and the colored product approximately stable for about $3 \mathrm{~h}$. So, the absorbance readings were taken immediately.

\section{Validation of the proposed methods}

Linearity and concentration ranges: Under the specified optimum conditions, the calibration curves for the determination of MCP either with Method A, Method B and Method C were constructed. A good linear relationship was observed within the ranges of 1.35-40.37, 1.01-5.05 and 1.01-10.09 $\mu \mathrm{g} / \mathrm{mL}$ at 426, 386 and $543 \mathrm{~nm}$ for Method A, Method B and Method C, respectively. The molar absorptivity $(\varepsilon)$ values were calculated from the slope of the calibration graphs and it was found as $1.51 \times 10^{4}, 2.10 \times 10^{4}$ and $3.34 \times 10^{4} \mathrm{~L} \mathrm{~mol}^{-1} \mathrm{~cm}^{-1}$ for DPP, HBD and ESN. The Limits of Detection (LOD) and Quantification (LOQ) were calculated as $3.3 \sigma / \mathrm{b}$ and $10 \sigma / \mathrm{b}$, respectively, where $\sigma$ is the standard deviation of five reagent blank determinations and $\mathrm{b}$ is the slope of the calibration curve. The calculated LOD values were $0.669,0.135$ and $0.124 \mu \mathrm{g} / \mathrm{mL}$, while LOQ were found to be 2.23, 0.453 and $0.414 \mu \mathrm{g} / \mathrm{mL}$, for Method A, Method $\mathrm{B}$ and Method C, respectively. The precision of the methods used for MCP determination was calculated [57] using 5 identical samples containing $1.35,4.04$ and $3.03 \mu \mathrm{g} / \mathrm{mL} \mathrm{MCP}$, respectively. Relative Standard Deviations (RSD) did not exceed $2 \%$ indicating the good reproducibility of the proposed methods. However, Table 2 illustrates the statistical analysis data for the proposed methods. Based on above data, we can conclude that Method C is more sensitive than Method A and Method B.

\begin{tabular}{|l|l|l|l|}
\hline Parameter & Method A & Method B & Method C \\
\hline Linearity range $(\mu \mathrm{g} / \mathrm{mL})$ & $1.35-40.37$ & $1.01-5.05$ & $1.01-10.09$ \\
\hline$\lambda_{\max }(\mathrm{nm})$ & 426 & 386 & 543 \\
\hline$\varepsilon\left(\mathrm{Lmol}^{-1} \mathrm{~cm}^{-1}\right)$ & $1.51 \times 10^{4}$ & $2.10 \times 10^{4}$ & $3.34 \times 10^{4}$ \\
\hline $\begin{array}{l}\text { Sandell's sensitivity }(\mu \mathrm{g} / \\
\left.\mathrm{cm}^{2}\right)\end{array}$ & 0.022 & 0.016 & 0.012 \\
\hline Correlation coefficient $(\mathrm{r})^{\prime}$ & 0.999 & 0.9993 & 0.9997 \\
\hline Regression equation $(\mathrm{Y}))^{\mathrm{a}}$ & $\begin{array}{l}\mathrm{A}=0.044 \mathrm{C}+1.5 \times \\
10^{-2}\end{array}$ & $\begin{array}{l}\mathrm{A}=0.062 \\
+2.5 \times 10^{-3}\end{array}$ & $\begin{array}{l}\mathrm{A}=0.087 \\
+7.2 \times 10^{-4}\end{array}$ \\
\hline R.S.D, $\%(\mathrm{n}=5)$ & 1.88 & 1.41 & 1.27 \\
\hline LOD $(\mu \mathrm{gg} / \mathrm{mL})^{\mathrm{b}}$ & 0.669 & 0.135 & 0.124 \\
\hline LOQ $(\mu \mathrm{g} / \mathrm{mL})^{\mathrm{b}}$ & 2.23 & 0.453 & 0.414 \\
\hline
\end{tabular}

Table 2: Statistical analysis for the spectrophotometric determination of MCP using either of the proposed procedures. ${ }^{\mathrm{a}} \mathrm{A}=\mathrm{b} \mathrm{C}+\mathrm{a}$ where $\mathrm{A}$ is absorbance and $\mathrm{C}$ is the MCP concentration $(\mu \mathrm{g} / \mathrm{mL}),{ }^{b} \mathrm{LOD}=3.3 \sigma / \mathrm{b}$ and $\mathrm{LOQ}=10 \sigma / \mathrm{b}$ where $\sigma=$ standard deviation of the blank and $b=$ slope of the regression 
Citation: Naggar AH, Elnasr TAS, Sayed Ali AS, Kotb A, El Sayed AAY (2017) Determination of Metoclopramide Hydrochloride in Pharmaceutical Formulations Using Three Different Spectrophotometric Methods. Pharm Anal Acta 8: 538. doi: $10.4172 / 2153-2435.1000538$

Page 6 of 9

\begin{tabular}{|c|c|c|c|c|c|c|c|c|}
\hline Reaction & Reagent & $\lambda_{\max }$ & $\varepsilon \times 10^{4^{*}}$ & Linearity range $^{* *}$ & LOD* $^{* *}$ & $\operatorname{LOQ}^{* *}$ & Remarks & Ref \\
\hline \multirow[t]{13}{*}{$\begin{array}{l}\text { Coupling } \\
\text { Reaction }\end{array}$} & $\begin{array}{l}\text { Benzoylaceton } \\
\text { e }\end{array}$ & 411 & 2.97 & $0.8-13.2$ & 0.0332 & 0.1006 & Use an organic solvent & [20] \\
\hline & Resorcinol & 440 & - & $20-100$ & - & - & Less sensitive & [26] \\
\hline & $\begin{array}{l}\text { Doxycycline } \\
\text { hyclate }\end{array}$ & 452 & 3.81 & $0.1-10$ & 0.012 & 0.043 & $\begin{array}{l}\text { Narrow concentration range } \\
\text { and use an expensive } \\
\text { reagent }\end{array}$ & [27] \\
\hline & Acetyl acetone & 430 & 2.2 & $2-16$ & 0.044 & 0.1334 & Use an organic solvent & [28] \\
\hline & $\begin{array}{l}2,5- \\
\text { Dimethoxyanilin } \\
\text { e }\end{array}$ & 486 & 4.55 & $0.1-12$ & 0.016 & 0.054 & Use an organic solvent & [29] \\
\hline & Diphenylamine & 530 & 4.73 & $0.3-7.5$ & 0.22 & 0.67 & $\begin{array}{l}\text { Narrow concentration range } \\
\text { and use an organic solvent }\end{array}$ & [30] \\
\hline & A-Naphthol & 550 & 3.49 & $0.4-18$ & 0.5448 & - & Use an organic solvent & [31] \\
\hline & Aniline & 410 & 3.53 & $0.5-12$ & 0.047 & 0.156 & $\begin{array}{l}\text { Use an organic solvent and } \\
\text { require heating }\end{array}$ & [32] \\
\hline & $\begin{array}{l}\text { Dibenzoyl } \\
\text { methane }\end{array}$ & 440 & 2.85 & $1-12$ & 0.0333 & 0.1009 & Use an organic solvent & {$[33]$} \\
\hline & $\begin{array}{l}\text { Imipramine } \\
\text { hydrochloride }\end{array}$ & 570 & 4.5 & $0.5-5$ & 0.0144 & 0.0437 & $\begin{array}{l}\text { Narrow concentration range } \\
\text { and use an expensive } \\
\text { reagent }\end{array}$ & [34] \\
\hline & $\begin{array}{l}\text { Chromtropic } \\
\text { acid }\end{array}$ & 540 & 0.416 & $2-24$ & - & - & $\begin{array}{l}\text { Less sensitive and use an } \\
\text { expensive reagent }\end{array}$ & [35] \\
\hline & B-Napthol & 553 & 2.74 & $1-10$ & - & - & Narrow concentration range & {$[36]$} \\
\hline & $\begin{array}{l}2,5- \\
\text { diphenyl-2,4- } \\
\text { dihydro- } \\
\text { pyrazol-3-one } \\
\text { (DPP) }\end{array}$ & 426 & 1.51 & $1.35-40.37$ & 0.669 & 2.23 & & This work \\
\hline \multirow[t]{5}{*}{ Schiff's Base } & $\begin{array}{l}\text { 4- } \\
\text { Dimethylamino } \\
\text { benzaldehyde }\end{array}$ & 438 & 0.211 & $10-100$ & - & - & Less sensitive & [36] \\
\hline & $\begin{array}{l}1,2- \\
\text { Naphthoquinon } \\
\text { e-4-sulphonate }\end{array}$ & 471 & 4.124 & $0.1-26$ & 0.0416 & 0.1386 & $\begin{array}{l}\text { Use cetylpyridinium } \\
\text { chloride as surfactant and } \\
\text { required heating }\end{array}$ & [37] \\
\hline & $\begin{array}{l}\text { p- } \\
\text { Dimethylamino } \\
\text { cinnamaldehyd } \\
\mathrm{e}\end{array}$ & 548 & - & $5-30$ & - & - & $\begin{array}{l}\text { Less sensitive and use an } \\
\text { organic solvent }\end{array}$ & [38] \\
\hline & Vanilin & 410 & 1.89 & $1.50-15.0$ & 0.510 & 1.55 & Less sensitive & [39] \\
\hline & $\begin{array}{l}\text { 4- } \\
\text { Hydroxybenzal } \\
\text { dehyde (HBD) }\end{array}$ & 386 & 2.10 & $1.01-5.05$ & 0.135 & 0.453 & & This work \\
\hline \multirow[t]{2}{*}{$\begin{array}{l}\text { Ion-pair } \\
\text { complex }\end{array}$} & $\begin{array}{l}\mathrm{Mo}(\mathrm{V}) \\
\text { thiocyanates } \\
\mathrm{Co}(\mathrm{II}) \\
\text { thiocyanates }\end{array}$ & $\begin{array}{l}472 \\
625\end{array}$ & $\begin{array}{l}1.90 \\
0.11\end{array}$ & $\begin{array}{l}1-20 \\
20-240\end{array}$ & - & - & $\begin{array}{l}\text { Require extraction step } \\
\text { using an organic solvent }\end{array}$ & {$[40]$} \\
\hline & $\begin{array}{l}\text { Bromothymol } \\
\text { Blue }\end{array}$ & - & - & $1-10$ & - & - & Use an organic solvent & [41] \\
\hline
\end{tabular}


Citation: Naggar AH, Elnasr TAS, Sayed Ali AS, Kotb A, El Sayed AAY (2017) Determination of Metoclopramide Hydrochloride in Pharmaceutical Formulations Using Three Different Spectrophotometric Methods. Pharm Anal Acta 8: 538. doi: $10.4172 / 2153-2435.1000538$

Page 7 of 9

\begin{tabular}{|l|l|l|l|l|l|l|l|l|}
\hline & Eosin Y (ESN) & 543 & 3.34 & $1.01-10.09$ & 0.124 & 0.414 & - & This work \\
\hline
\end{tabular}

Table 3: Comparison between the proposed procedures and other correspondence procedures used for spectrophotometric determination of MCP. ${ }^{\star}$ Molar Absorptivity $(\varepsilon)$ in $\mathrm{Lmol}^{-1} \mathrm{~cm}^{-1},{ }^{\star *}$ Linearity range, Lower limit of detection (LOD) and Lower limit of quantifcation (LOQ) in $\mu \mathrm{g} / \mathrm{mL}$.

Interferences study: For all proposed methods, the influence of diverse ions on the determination of $2.018 \mu \mathrm{g} / \mathrm{mL}$ MCP was conducted by added various concentration of different salts in which anions may be chloride, nitrate or sulfate, and the cations as $\mathrm{Al}^{+3}, \mathrm{Ca}^{+2}, \mathrm{Sr}^{+2}, \mathrm{Cd}^{+2}$, $\mathrm{Ni}^{+2}, \mathrm{Co}^{+2}, \mathrm{Mg}^{+2}, \mathrm{Cu}^{+2}$ and $\mathrm{NH}^{4+}$. Also, in presence of $2.018 \mu \mathrm{g} / \mathrm{mL}$ $\mathrm{MCP}$, another interference study was conducted by addition of several concentrations of some common excipients and additives which used in pharmaceutical preparations (e.g. glucose, sucrose, lactose and fructose). Either studies was conducted in presence of equimolar concentration or even at higher molar excess (10000:1) (foreign ion/ excipient: MCP) under the optimum experimental conditions. The obtained results revealed that no interference was observed from any of these excipients with the proposed methods. The calculated recovery value was $98.3-099.5 \pm 0.10 \%$. The obtained results indicate that there is no interference may be occurred from these excipients.

It was mentioned that drugs usually eliminated from body principally by urinary excretion [1]. In case of MCP, as reported in official methods $[58,59]$, about $60 \%$ of an oral dose is excreted in human urine in the first $24 \mathrm{~h}$. So, the proposed methods for spectrophotometric determination of MCP in this work can be easily applied without any interfere can be occurred as a result of MCP distribution in human body. The same result we had got before in earlier work [6].

Comparison with other spectrophotometric methods: In comparison with the other spectrophotometric methods used for MCP determination, the proposed methods utilizing DPP, HBD and ESN have the advantage of being simple, reproducible, time saving, highly selective and sensitive. Table 3 summarizes the analytical characteristics of the proposed methods along with frequently used spectrophotometric methods for MCP determination.

Application of the proposed methods: The applicability of either of the developed methods was investigated when used for the determination of MCP in different pharmaceutical preparations; Primperan tablets and Plasil ampoules. The validity of the proposed methods was assessed by applying the standard addition method. The obtained results summarized in Table 4 shows satisfactory recoveries and confirmed the validity and the accuracy of the proposed methods. The results given by the proposed methods and the reference method [59] were statistically compared.

\begin{tabular}{|c|c|c|c|c|c|c|c|c|}
\hline \multirow[t]{2}{*}{ Preparations } & \multirow{2}{*}{$\begin{array}{l}\text { Added MCP } \\
(\mu \mathrm{g} / \mathrm{mL})\end{array}$} & \multicolumn{2}{|c|}{ Method A } & \multicolumn{2}{|c|}{ Method B } & \multicolumn{2}{|c|}{ Method C } & \multirow[t]{2}{*}{$\begin{array}{l}\text { Reference } \\
\text { MCP }(\mu \mathrm{g} / \mathrm{mL})\end{array}$} \\
\hline & & Found $^{a}$ & $\mathbf{s}$ & Found $^{a}$ & $\mathbf{s}$ & Found $^{a}$ & $\mathbf{s}$ & \\
\hline \multirow{6}{*}{ Primperan (tablets) ${ }^{\mathrm{b}}$} & - & 1.66 & 0.008 & 1.537 & 0.01 & 1.662 & 0.007 & 1.62 \\
\hline & 1.01 & 2.664 & 0.007 & 2.555 & 0.003 & 2.65 & 0.012 & 2.623 \\
\hline & 1.73 & 3.383 & 0.005 & 3.285 & 0.004 & 3.41 & 0.003 & 3.359 \\
\hline & 2.47 & 4.129 & 0.003 & 4.044 & 0.013 & 4.12 & 0.006 & 4.098 \\
\hline & 3.25 & 4.905 & 0.004 & 4.759 & 0.009 & 4.905 & 0.004 & 4.856 \\
\hline & 4 & 5.596 & 0.014 & 5.473 & 0.015 & 5.596 & 0.014 & 5.555 \\
\hline \multirow{6}{*}{ Plasil (ampoules) ${ }^{c}$} & - & 1.645 & 0.011 & 1.545 & 0.005 & 1.652 & 0.013 & 1.614 \\
\hline & 1.01 & 2.655 & 0.007 & 2.545 & 0.007 & 2.661 & 0.008 & 2.62 \\
\hline & 1.73 & 3.375 & 0.004 & 3.27 & 0.009 & 3.395 & 0.007 & 3.347 \\
\hline & 2.47 & 4.114 & 0.005 & 3.958 & 0.008 & 4.117 & 0.006 & 4.063 \\
\hline & 3.25 & 4.855 & 0.012 & 4.729 & 0.016 & 4.851 & 0.015 & 4.812 \\
\hline & 4 & 5.615 & 0.009 & 5.535 & 0.003 & 5.615 & 0.01 & 5.588 \\
\hline
\end{tabular}

Table 4: Spectrophotometric determination of MCP in dosage forms by standard addition method. average of five separate measurements, ${ }^{b}$ Labeled to contain $10 \mathrm{mg}$ MCP per tablet, ${ }^{c}$ Labeled to contain $10 \mathrm{mg}$ MCP per ampoule

\section{Conclusion}

2,5-diphenyl-2,4-dihydro-pyrazol-3-one (DPP), 4-hydroxy benzaldehyde (HBD) and Eosin Y (ESN) were presented in this work as a new reagents for the spectrophotometric determination of MCP. The suggested procedures have the advantages of being simple, reproducible and inexpensive. The optimum experimental conditions for each method were studied in details. The proposed methods were 
Citation: Naggar AH, Elnasr TAS, Sayed Ali AS, Kotb A, El Sayed AAY (2017) Determination of Metoclopramide Hydrochloride in Pharmaceutical Formulations Using Three Different Spectrophotometric Methods. Pharm Anal Acta 8: 538. doi: $10.4172 / 2153-2435.1000538$

Page 8 of 9

selective, accurate and precise as indicated by the good recoveries of two different series of MCP and low RSD values. Either of the proposed methods was successfully applied for the determination of MCP in pharmaceutical formulations.

\section{References}

1. Martindal (2000) "The Extra Pharmacopoeia" (46th edn.). The Pharmaceutical Press, London, p: 1200.

2. Vandenplas Y, Hauser B (2015) An updated review on gastroesophageal reflux in pediatrics. Expert Rev Gastroenterol Hepatol 9: 1511-1521.

3. Tas C, Ozkan CK, Savaser A, Ozkan Y (2006) Nasal absorption of metoclopramide from different Carbopol $^{\oplus} 981$ based formulations: In vitro, ex vivo and in vivo evaluation. Eur J Pharm Biopharm 64: 246-254.

4. Guo W, Geng M, Zhou L (2012) Electrochemistry of metoclopramide at multi-walled carbon nanotube modified electrode and its voltammetric detection. Anal Sci 28: 693-698.

5. Dejmkova H, Dag C, Barek J, Zima J (2012) Voltammetric and amperometric determination of metoclopramide on boron-doped diamond film electrode, Cent Eur J Chem 10: 1310-1317.

6. Farghaly OA, Taher MA, Naggar AH, El-Sayed AY (2005) Square wave anodic stripping voltammetric determination of metoclopramide in tablet and urine at carbon paste electrode. J Pharm Biomed Anal 38: 14-20.

7. Wang ZH, Zhang HZ, Zhou SP, Dong WJ (2001) Determination of trace metoclopramide by anodic stripping voltammetry with nafion modified glassy carbon electrode. Talanta 53: 1133-1138.

8. Xiao-xia L, Wen-qin Z, Li-xiao M, Qi-rui L (2010) Electrochemical determination of metoclopramide hydrochloride and its interaction with bovine serum albumin. J Instrum Anal 11: 1126-1131.

9. Patil SM, Nandibewoor ST (2015) Electrochemical behavior of antiemetic drug metoclopramide at electrochemically pre-treated pencil graphite electrode. Anal Bioanal Electrochem 7: 387-400.

10. Shahrokhian S, Naderi L, Ghalkhani M (2015) Nanocellulose/carbon nanoparticles nanocomposite film modified electrode for durable and sensitive electrochemical determination of metoclopramide, Electroanalysis 27: 2637-2644.

11. Faridbod F, Ganjali MR, Labbafi S, Dinarvand R (2009) A new metoclopramide potentiometric membrane sensor for analysis in pharmaceutical formulation and urine: concerns to theoretical study. Int J Electrochem Sci 4: 772-786.

12. Diaz C, Vidal JC, Galban J (1989) Potentiometric determination of metoclopramide using a double-membrane based ion-selective electrode. J Electroanal Chem Interfacial Electrochem 258: 295-302.

13. Ghonim OAA (2014) PVC membrane sensors for potentiometric determination of metoclopramide in pharmaceutical preparations and in presence of its degradate. Anal Bioanal Electrochem 6: 296-307.

14. Fatmi AA, Williams GV (1989) Analysis of metoclopramide and related compounds in tablets by liquid chromatography. Drug Dev Ind Pharm 15: 1365-1373.

15. Bayrak Z, Kurbanoglu S, Savaser A, Ozkan SA (2014) LC-MS method for the sensitive determination of metoclopramide: application to rabbit plasma, gel formulations and pharmaceuticals. Chromatographia 77: 99-107.

16. Yan M, Li HD, Chen BM, Liu XL, Zhu YG (2010) Determination of metoclopramide in human plasma by LC-ESI-MS and its application to bioequivalance studies. J Chromatogr B 878: 883-887

17. Tatar US (2012) High performance liquid chromatography for the determination of metoclopramide in pharmaceutical preparations using pre-column derivatization with fluorescamine. Chin J Chem 30: 634-638.

18. Foda NH (1994) Quantitative analysis of metoclopramide in tablet formulations by HPLC. Anal Lett 27: 549-559.

19. Belal FF, Sharaf El-Din MK, Tolba MM, Elmansi H (2014) Derivative spectrophotometric and liquid chromatographic methods for the simultaneous determination of metoclopramide hydrochloride and aspirin in pharmaceuticals. J Chromatogr Sci 52: 1224-1232.
20. Omran AA (2005) Individual and simultaneous spectrophotometric determination of dapsone and metoclopramide $\mathrm{HCl}$ in pharmaceutical dosage forms and synthetic binary mixtures. Chem Pharm Bull 53: 1498-1501.

21. Deokate UA, Gorde AM (2014) A stability indicating UV specrophotometric method for determination of metoclopramide hyrdrochloride. Int J Pharm Pharm Sci 6: 394-397.

22. Thangamani A, Smith AA, Vedhapriya B (2014) Development of analytical method for metoclopramide using UV-spectrophotometry. Int J Pharm Chem Biol Sci (IJPCBS) 4: 551-555.

23. Wadher SJ, Pathankar PR, Puranik M, Ganjiwale RO, Yeole PG (2008) Simultaneous spectrophotometric estimation of paracetamol and metoclopramide hydrochloride in solid dosage form. Indian J Pharm Sci 70: 393-395.

24. Silva IS, Saraiva M Lúcia MFS, Santos JLM, Lima JLFC (2007) Sequential injection spectrophotometric determination of metoclopramide in pharmaceutical preparations. Spectrosc Lett 40: 51-61.

25. Fan J, Wang A, Feng S, Wang J (2005) Non-equilibrium determination of metoclopramide and tetracaine hydrochloride by sequential injection spectrophotometry. Talanta 66: 236-243.

26. Pratapareddy AJ (2015) new spectrophotometric determination of metoclopramide in bulk and pharmaceutical dosage form. J Drug Discovery Ther 3: 1-4.

27. Alshirifi AN, Abbas MH (2015) New spectrophotometric method for the determination of metoclopramide hydrochloride in pharmaceutical preparations based on coupling with doxycycline hyclate. Int J Chem Sci 13: 1093-1108.

28. Revanasiddappa HD, Manju B (2002) Spectrophotometric determination of some chemotherapeutic agents using acetyl acetone. Drug Dev Ind Pharm 28: 515-521.

29. Jawad AA, Kadhim KH (2013) Spectrophotometric determination of metoclopramide hydrochloride in bulk and pharmaceutical preparations by diazotization-coupling reaction. Int J Pharm Pharm Sci (IJPPS) 15: 294-298.

30. Devi OZ, Basavaiah K, Vinay KB, Revanasiddappa HD (2012) Determination of metoclopramide hydrochloride in pharmaceuticals and spiked human urine through diazotization reaction. J Food Drug Anal 20: 454-463.

31. Sinan R (2010) Spectrophotometric determination of metoclopramide hydrochloride in pharmaceutical tablets, by diazotization-coupling method with 1-naphthol as coupling agent. Baghdad Sci J 7: 704-712.

32. Shah J, Rasul Jan M, Khan MA, Amin S (2005) Spectrophotometric determination of metoclopramide in pharmaceutical preparations. J Anal Chem 60: 633-635.

33. Revanasiddappa HD, Manju B (2001) A spectrophotometric method for the determination of metoclopramide $\mathrm{HCl}$ and dapsone. J Pharm Biomed Anal 25: 631-637.

34. Revanasiddappa HD, Veena MA (2006) Sensitive spectrophotometric determination of metoclopramide hydrochloride and dapsone in bulk sample and dosage forms. Science Asia 32: 319-321.

35. Ramappa PG, Revanasiddappa S, Revanasiddappa HD (1999) A facile spectrophotometric determination of metoclopramide hydrochloride in pharmaceutical dosage forms. Indian Drugs 36: 381-384.

36. Patel SA, Patel CN, Patel MM (2006) Visible spectrophotometric methods for the estimation of metoclopramide hydrochloride in tablets. Indian J Pharm Sci 68: 397-399.

37. Al-Azzawi HAW, Al-Obadi FM, Al-Sabha TN (2015) Spectrophotometric assay of metoclopramide hydrochloride in bulk and in dosage form. Iraqi National J Chem 15: 59-76.

38. Moussa BA (2000) Determination of some aminobenzoic acid derivatives: Glafenine and metoclopramide. J Pharm Biomed Anal 23: 1045-1055.

39. Devi OZ, Basavaiah K, Vinay KB, Revanasiddappa HD (2017) Sensitive spectrophotometric determination of metoclopramide hydrochloride in dosage forms and spiked human urine using vanillin. Arabian J Chem 26. 
Citation: Naggar AH, Elnasr TAS, Sayed Ali AS, Kotb A, El Sayed AAY (2017) Determination of Metoclopramide Hydrochloride in Pharmaceutical Formulations Using Three Different Spectrophotometric Methods. Pharm Anal Acta 8: 538. doi: $10.4172 / 2153-2435.1000538$

Page 9 of 9

40. Abdel-Gawad FM, El-Guindi NM (1995) Spectrophotometric determination of metoclopramide and oxybuprocaine through ion pair formation with thiocyanate and molybdenum(V) or Cobalt(II). Anal Lett 28: 1437-1447.

41. Shingbal DM, Velingkar VS (1988) Note on colorimetric determination of metoclopramide hydrochloride in dosage forms. Indian Drugs 25: 529-531.

42. Li YL, Kan LH, Chuan LJ, Hua WY (2010) Spectrophotometric determination of metoclopramide based on its charge transfer reaction with chloranilic acid. Physical Testing and Chemical Analysis (Part B: Chemical Analysis) 8: 906-907.

43. El-Gendy AE (1992) Spectrophotometric determination of metoclopramide via charge transfer complexes. Spectro Lett 25: 1297-1313.

44. Devi OZ, Basavaiah K, Vinay KB (2012) Application of potassium permanganate to spectrophotometric assay of metoclopramide hydrochloride in pharmaceuticals. J Appl Spectrosc 78: 873-883.

45. Shekho NH, Al-Sarraj TZ (2013) Spectrophotometric assay of metoclopramide hydrochloride in pharmaceutical preparations via arsenazo III-cerium (III) reaction. Raf J Sci 24: 70-83.

46. Elmansi H, Mohamed SA, Fathy ME (2016) Simultaneous determination of metoclopramide and aspirin by spectrofluorimetric technique: application to pharmaceutical formulations and human plasma. Anal Methods 8: 1281-1292.

47. Rao HL, Aroor AR, Rao PG (1991) Fluorimetric estimation of metoclopramide in dosage forms. Indian Drugs 28: 195-196.

48. El-Enany N (2008) Second derivative synchronous fluorescence spectroscopy for the simultaneous determination of metoclopramide and pyridoxine in syrup and human plasma. J AOAC Int 91: 542-550.
49. Kost AN, Grandberg II (1966) Progress in pyrazole chemistry. Adv Heterocycl Chem 6: 347-429

50. Bates RG, Bower VE (1956) Alkaline solutions for $\mathrm{pH}$ control. Anal Chem 25: 1322-1324.

51. McIlvaine TC (1921) A buffer solution for colorimetric comparison. J Biol Chem 49: 183-186.

52. Annapurna V, Jyothi G, Rambabu C, Sailaja BBV (2009) Spectrophotometric determination of ceftiofur hydrochloride using Nbromosuccinimide and p-dimethylaminobenzaldehyde. E-J Chem 6: 763-769.

53. Batistela VR, Pellosi DS, de Souza FD, da Costa WF (2011) pKa determinations of xanthene derivates in aqueous solutions by multivariate analysis applied to UV-Vis spectrophotometric data. Spectrochim Acta A 79: 889-897.

54. Zhebentyaev AL, Zhernosek AK (1996) Extraction-spectrophotometric determination of berberine sulfate in tablets using eosin as a reagent. Pharmazie 51: 252-255.

55. Gazy AA, Mahgoub H, El-Yazbi FA, El-Sayed MA, Youssef RM (2002) Determination of some histamine H1-receptor antagonists in dosage forms. J Pharm Biomed Anal 30: 859-867.

56. El-Brashy AM, Metwally MS, El-Sepai FA (2004) Spectrophotometric determination of some fluoroquinolone antibacterials by binary complex formation with xanthene dyes. Il Farmaco 59: 809-817.

57. Miller JC, Miller JN (1994) Statistics for Analytical Chemistry (4th edn.). Ellis-Howood, NY, USA.

58. Pitre D, Stardi R (1982) Analytical Profiles of Drug Substances, Academic Press, Orlando, p: 327.

59. British Pharmacopoeia (1998)The Stationary Office under License from the Controller of Her Majesty's Stationary Office, London, p: 506. 